Author post-print available under Creative Commons License. Published as Peter Alagona, John Sandlos, and Yolanda Wiersma, "Past Imperfect: Using Historical Ecology and Baseline Data for Contemporary Conservation and Restoration Projects," Environmental Philosophy Vol. 9, No. 1 (2012): 49-70. DOI:10.5840/envirophil2012914

\title{
Past Imperfect:
}

Using Historical Ecology and Baseline Data for Conservation and Restoration Projects in North America

Peter S. Alagona

Assistant Professor

Department of History \& Environmental Studies Program

4231 Humanities \& Social Sciences Building

University of California

Santa Barbara, CA 93106-9410

Email: alagona@history.ucsb.edu

John Sandlos

Associate Professor

Department of History

Memorial University of Newfoundland

St. John's, NL

A1C 5S7, Canada

Email: jsandlos@mun.ca

Phone: (709) 864-2429

Fax: (709) 864-2164

Yolanda F. Wiersma

Assistant Professor

Department of Biology, Memorial University

St. John's NL, Canada

A1B 3X9

Email: ywiersma@mun.ca

Ph. 709.864.7499

Fax 709.864.3018 


\section{Past Imperfect:}

Using Historical Ecology and Baseline Data

for Conservation and Restoration Projects in North American

\section{Introduction}

Conservation almost always involves nostalgic claims about the past-along with calls to return to that past or recapture some aspect of it. Activists, scholars, and practitioners regularly invoke images of historical abundance and subsequent decline in their pleas to preserve what is left of wild nature, and they use these images to promote programs that aim to return ecosystems to their natural, or "original," conditions. Such calls span the diversity of environmental discourse-from the conservation of endangered species, to the restoration of ecosystems, to the re-wilding of entire landscapes and even the North American continent. We must protect or restore species, ecosystems, and landscapes, the argument goes, because at some time in the past the world was so much more productive and diverse.

The basic logic behind this position is unassailable. How can we conserve or restore species and ecosystems without history as a guide? More specifically, how many wolves once roamed the lower 48 states, and how much suitable habitat would be needed to restore the species to its former range? What kind of burning regime is required to maintain and regenerate jack pine and other fire dependent tree species in managed wilderness areas? And what kinds of stream and lake conditions are necessary to bring Atlantic salmon back to the Great Lakes? All of these questions involve problems of time in that they demand some reckoning with the past-a backward looking attempt to reconcile conservation and restoration goals with environmental conditions as they once were. All of these questions also involve problems of space in that they require us to consider the scale of our restoration ambitions.

Yet the use of history as a guide to conservation and restoration programs is fraught with challenges. On a methodological level, conservationists and restorationists too often adopt historical 
baseline data uncritically, using early accounts of wildlife numbers or ecological conditions without closely examining the manner in which these accounts were recorded, transmitted, and interpreted by past generations. Such accounts often involved a high degree of guesswork and extrapolation, a problem compounded by the fragmentary nature of documentary and oral records, which calls into question the idea that the past is knowable and accessible to the contemporary observer (Lowenthal 1985). The use of historical ecological data as a contemporary reference point has also been challenged on the grounds that ecosystems are dynamic, fluid, and always changing, which makes it difficult to identify a single moment in time as the goal for contemporary conservation and restoration programs (Jackson and Hobbs 2009). The historian William Cronon (1993) has suggested that the past serves as only the coarsest guide to the future, providing parables about environmental change but no clear path forward as ecosystems always shift and change in unpredictable ways. Moreover, because climatic and environmental conditions are always changing, it would be impossible simply to rewind history and reestablish any past ecosystem.

These observations are not new. Scholars from a variety of fields have increasingly recognized that although the past can provide crucial information about possible future conditions, it cannot serve as exact template for restoration in an ever-changing world (Dizard 2010, Harris et al. 2006, Jentsch 2007, Kloor 2000, Myllantaus 2010, Stewart 2010). Yet there have been few attempts to document the history of efforts to establish ecological baselines for science and conservation, or the challenges that managers have encountered when they have tried to use baseline historical data for restoration at multiple scales of biological organization.

In this paper we describe the development of the baselines concept, and we examine the opportunities and pitfalls associated with the use of historical data as a baseline for conservation and restoration. To do so, we focus on three levels of biological organization: individual species, restoration sites, and broader landscapes. The baselines concept was central to the emergence of ecology in North 
America nearly a century ago. But it was problematic then, and it remains problematic today when used as a goal for restoration. This does not mean that historical knowledge is unimportant for contemporary environmental management, but rather that such knowledge must derive from a serious engagement with the complexity of change over time instead of a narrow attempt to re-establish the pristine conditions that existed in some imagined past. Such a serious engagement would include not only speculation about primeval ecological conditions, but also changing human perceptions and social and political debates over lands and natural resources. History will remain crucial for conservation and restoration whether or not we can agree on specific ecological baselines.

\section{The Species}

Naturalists have been trying to establish baselines for wild plant and animal populations since before ecology emerged as a scientific discipline. In North America, these efforts began with maps and censuses that attempted to inventory a continent many European newcomers believed was not substantially or permanently altered by indigenous human activities. As many scholars have noted, this belief provided a justification for European settlers to usurp lands and natural resources that they considered free for the taking (Cronon 1983). For the naturalists and explorers who fanned out over the continent during the eighteenth and nineteenth centuries, however, North America was seen as a primeval wilderness that contained its entire cast of native species. To map and count the populations of these species was to view nature in its raw, primeval state (Kohler 2006).

During the late nineteenth century, naturalists estimated the populations of some of the continent's most conspicuous game species. Their efforts were motivated in part by scientific interest, but even more by a desire to quantify the spectacular declines of charismatic native species, such as the plains bison. Authors would usually begin with the accounts of earlier explorers and surveyors. They would then combine this information with contemporary indicators, such as the population densities of 
the domestic and feral livestock that had replaced native species on the range. This would render a crude estimate of "carrying capacity." This number would then be extrapolated to cover the wild species' presumed historical range. The naturalist, author, and educator, Ernest Thompson Seton (1927), used this technique in the 1920 s to calculate a pre-contact bison population of 65 million animals, which he considered a "safe estimate."

Seton's approach involved several assumptions. Early explorers' accounts were fragmentary, ambiguous, and impressionistic, and they were often crafted more to serve political or institutional objectives than to provide rigorous documentation of ecological phenomena (Anderson, Barbour, and Whitworth 1997). It is unclear what contemporary populations of domestic species could reveal about past populations of wild species. Range maps often relied on conjecture, and they failed to account for differences in population densities across the species' range (Shelton and Weckerly 2007). Seton's approach ignored indigenous human activities, including changes in those activities over time such as the adoption of guns and horses. It also assumed that "historic conditions" were static, timeless, and deterministic, rather than dynamic, changeable, and contingent, which is the view embraced by most scholars today (Foster et al. 2002). Indeed, in some cases, the wildlife populations documented by settlers and explorers may have been unusually large, due to declines in indigenous hunting and gathering during the preceding decades (Preston 2002). Despite these shortcomings, nineteenth century estimates of past animal populations profoundly shaped the belief that, before European contact, North America was a place of almost unimaginable wildlife diversity and abundance.

Another effort emerged, around the same time, to document the "original" fauna of North America and thus establish a baseline for future studies. The natural history collection craze began in the eighteenth century with privately owned "cabinets of curiosity" (Leviton and Aldrich, eds., 2004). Many of the most accomplished collectors eventually donated or willed their cabinets to fledgling public and university museums, which underwent a period of impressive growth during the Progressive era, from 
about 1880 to 1920 . Some of these museums were exhibition-oriented, and thus worked to develop collections of exotic species with the most popular appeal, but others were more research-oriented and regionally focused.

The Museum of Vertebrate Zoology, at the University of California, Berkeley, was one example of the latter (Star and Griesemer 1989). Its founder, the noted zoologist and evolutionary biologist Joseph Grinnell, sought to compile a meticulously organized and documented collection of vertebrate specimens from around that diverse state. Grinnell began his work in 1908 at a time of great landscape change in California, and he and his assistants raced from site to site collecting specimens of rare and endemic species before those creatures disappeared. According to Grinnell, the value of these collections "might not be realized until the lapse of many years, possibly a century, assuming that our material is safely preserved" (Grinnell 1910). Yet he believed such work was crucial so that "the student of the future will have access to the original record of faunal conditions in California and the west." For Grinnell, museum conservation was, in part, about establishing an ecological baseline for native species.

The field of ecology began to coalesce in the early 1900s, and the Ecological Society of America was founded in 1915. The emergence of this new field brought with it new approaches and motivations regarding the baseline concept. Ecologists in the United States set out not only to modernize traditional natural history research, but also to address the unintended consequences of westward expansion, population growth, resource extraction, and agricultural development. Researchers such as Victor Shelford, the first President of the Ecological Society of America, were among the earliest champions of the baseline idea. Shelford, who is also known as the father of animal ecology in America, established the Ecological Society's first Preservation Committee with the goal of inventorying and promoting the conservation of "natural areas." He believed that such areas would provide what he called "binonomic baselines," which ecologists could use to study animal interactions and population dynamics in relatively undisturbed environments (Barrow 2009). 
During the 1930s, two major developments made the concept of ecological baselines more prominent and relevant in science and conservation. The first was the emergence of the field of wildlife management. Early wildlife managers, such as the members of the U.S. National Park Service's Wildlife Division, argued for an approach that included history as a basis for setting administrative goals. For the Division's members, the first step in developing any management plan was to develop a "picture of the fauna of the area as it existed in its undisturbed environment before white men came" (Wright et al., 1933). This ethnocentric view replicated earlier ideas about the primeval wilderness, but it also provided a foundation for demonstration projects in restoration ecology.

Early restoration projects, led by figures such as Aldo Leopold and Herbert Stoddard, comprised the second major development of the 1930s. In the United States, New Deal agricultural bailouts and other economic recovery programs resulted in the creation of vast wildlife refuges on newly acquired public lands. These were often degraded former farms and ranches that offered unprecedented opportunities for experiments in management and restoration. Some early projects attempted to reestablish past ecological conditions, which required historical research dedicated to the identification of restoration targets. But many others, particularly in the post-War period, embraced large-scale ecological manipulation as a way of producing abundant game for recreational sportsmen (Wilson 2010).

In recent years, the idea of baselines has been particularly important in two areas of specieslevel ecological science and conservation. The first is marine conservation. The marine biologist Daniel Pauly's (1995) influential paper on the "shifting baselines syndrome of fisheries" argued that, with each succeeding generation, expectations of fisheries productivity declined among scientists, managers, and the public. Terms such as "normal" and "healthy" were applied to increasingly degraded systems due to intergenerational gaps in memory about the productivity and diversity of past marine environments (Jackson et al. 2011). Recent publications have extended the shifting baseline concept beyond fisheries 
to marine mammals, coral reefs, kelp forests, intertidal zones, and just about every other marine ecosystem (e.g., Lotze \& Worm 2008, Sáenz-Arroyo 2005, Vera 2010), and it has become a major publicity and educational tool for ocean conservation organizations.

Much of the marine science community has embraced the shifting baseline concept as an overarching framework for the history of the oceans, but as with all models of history, it is not without its problems (Anderson 2006). There is little longitudinal survey data available to characterize views on marine environments over time. This means that most supporting evidence must come from historical documents, but the primary sources are also equivocal. Some authors have always claimed that ocean fisheries are inexhaustible-and a few still do-but other authors have been noting the decline of marine resources in North America for four centuries (Bolster 2008, Kroll 2008). It is unclear how the shifting baseline concept might vary across space or apply to non-western societies, and it has not yet developed to the point where it can provide a rigorous framework for understanding the relations between science, policy, and popular beliefs. Scholars have yet to reconcile the shifting baselines idea, for example, with the large literatures in science and technology studies, science policy, or the public understanding of science. Finally, the shifting baseline concept implies that real baselines are available by which we can measure changes to ecological conditions and species populations, even though such baselines have proven elusive.

A second area of species-level science and conservation where ecological baselines play a pivotal role is in endangered species management. In the United States, which has the world's most powerful and comprehensive endangered species law, determinations of a species' eligibility for listing depend, in part, on the extent to which its population has declined. Assessing a decline requires a baseline, and in the vast majority of cases adequate data are missing. This means that biological conclusions of such research are almost always ambiguous, but the political and regulatory 
consequences can be severe. Two examples from California illustrate these challenges and their consequences in practice.

The desert tortoise was once apparently a common species throughout the Mojave and Sonoran deserts of the American Southwest. Little is known about its role in American Indian cultures, though its remains are found in middens through the region. The species declined during twentieth century due to a variety of factors, including collection for the food and pet trades. In the 1980s, biologists discovered that lethal disease similar to pneumonia had become an epidemic in the population, and the U.S. Fish and Wildlife Service (FWS) responded by using its emergency authority to protect desert tortoises under the federal Endangered Species Act.

Primary source documents for the desert tortoise were vague, and as with most endangered species, it was difficult to draw conclusions about the species former abundance. The biologist who researched the species' decline, Kristin Berry, had grown up in the desert and she relied heavily on oral history interviews for her data (Berry 1984). A few of Berry's colleagues expressed doubts about the reliability of this information, but a general consensus soon emerged that although the tortoise still occurred throughout its historical range, its densities had declined by up to 90 percent in some areas (Bury and Corn 1995). One consequence of this consensus was that the FWS designated 6.4 million acres (10,000 square miles) of the Mojave Desert-an area roughly the size of Massachusetts-as critical tortoise critical habitat. Any public or private project under federal jurisdiction in that area would require FWS consent.

Another example involves the southern steelhead. The steelhead is part of a larger "species complex" in which some individuals remain in fresh water throughout their lives and are known as rainbow trout, while others migrate into the ocean, undergo physiological changes, and return to spawn years later as steelhead. Rainbow trout have been bred and stocked on a vast scale since the nineteenth century and are not protected (Halverson 2010). Steelhead populations have declined due largely to 
changes in their spawning habitats, including the construction of dams, and they are now protected as endangered in the streams of Southern and Central California.

The region's Mediterranean climate-with its warm, dry summers and cool, wet winterscreates flashy, seasonal streams, and steelhead populations were probably well adapted to this dynamic environment. In the region's most productive streams, annual spawning steelhead numbers may have fluctuated by up five orders of magnitude. The National Oceanic and Atmospheric Administration (NOAA), which oversees marine and anadromous endangered species, is charged with the task of recovering southern steelhead. The very meaning of recovery is predicated on the notion of reaching targets based on credible baselines. Yet establishing such baselines has proven difficult for such a species with such fluid population dynamics living in such a dynamic environment. Few issues could be more important to people of the region because steelhead recovery programs will likely involve changes in the management of massive infrastructure projects that distribute water to the tens of millions of people who live in this semi-arid region. Numerical recovery targets predicated on a historical baseline population are often required to justify recovery and restoration programs for endangered species such as the steelhead, but such numbers may themselves be an abstraction, confounded by the complex and variable ecological history of the species in question.

\section{The Site}

The problem of determining appropriate baseline conditions for individual species presents many similar issues when attempting to establish a reference point for historical environmental conditions at a site specific location. Practitioners and philosophers of restoration ecology, and its more interdisciplinary and participatory cousin ecological restoration, have long debated the temporal and historical dimensions of so-called earth repair activities. At the initial stage of this debate, critics such as 
Robert Eliot and Eric Katz rejected the idea that a restored site could adequately reference its historical condition. Eliot $(1982,1997)$ invoked the analogy of art restoration to suggest that restored natural sites were in essence fakes, while Katz $(1992,1996,2002)$ suggested that restorationists produced only imperfect anthropogenic copies of ecosystems, a technological fix to environmental problems that reinforced the domineering presence of human culture within formerly natural landscapes. Drawing further on this notion, Eliot $(1982,1997)$ also argued that restoration granted humans an unbridled license to manage and manipulate nature, providing a ready-made apologia for developers who promised to return damaged sites such as mines and waste dumps to their former ecological condition.

In response to these attacks, scholars such as Andrew Light (2009) and Eric Higgs (2003, 2005) have argued first that practitioners should beware of "malicious" restoration projects that provide a politically problematic moral justification for unsustainable mega-developments, and second that restoration should aim not to recreate a perfect copy of previous ecological conditions but re-create conditions that allow for ecological processes and change to continue along a similar evolutionary path. For Light and Higgs, ecological restoration projects do not re-create works of art or museum pieces in a fixed and unchanging position, but must accommodate variation and transformation. William Jordon (2003) has similarly argued that the purpose of restoring of historical landscapes (he uses the term classic landscapes) is not to reproduce a fixed reproduction of an object or moment in time (as in the restoration of a painting or sculpture) but is more analogous to arts such as music or dance, where improvisation and the performative process remain much more important than the status of the artwork as artifact.

If the act of ecological restoration is focused on re-establishing process, change and flux, the problem of what point in time to mark as a restoration target remains paramount, as seen with the example of the steelhead trout, above. From early twentieth century, restoration ecologists and conservationists in North America have continually pointed to the so-called natural or wild landscapes of 
the pre-contact period as a baseline against which to evaluate current conditions (Hall 2007). European expansion in North America brought massive ecological changes with the introduction of Old World plants, animals and pathogens, particularly in the temperate latitudes (Crosby 1986, DeJohn Anderson 2004). As so many critics have pointed out, however, identifying the sixteenth century and all subsequent impacts as the major breaking point in North America's environmental history ignores the major anthropogenic and non-anthropogenic environmental changes that occurred prior to contact, particularly the widespread landscape changes associated with the aboriginal use of fire (Bjorkman and Vellend 2010, Denevan 1992, Krech 1999, Pyne 1997). Ecologists have had to adopt the idea that restoration goals are often a moving target, the re-creation of ecological conditions in specific sites in accordance with a continuum of historical change, rather than a return to a fixed moment in time (Hobbs 2007, Jentsch 2007, Kloor 2000, Lowenthal 2010, White and Walker 1997). This is particularly true in Europe, where the absence of a singular historical ecological shock event such as the North America contact period had compelled restoration ecologists to focus on re-establishing historical ecosystem processes and cultural landscapes in a manner that accounts for long-term human occupancy (agriculture, urban settlements, etc.) rather than supposedly pristine landscapes that existed prior to sudden and massive anthropogenic ecological change (Hall 2005, Pfadenhauer 2001).

The difficulty of identifying historical baseline conditions has prompted one wing of the restoration movement to abandon the past altogether. Focusing on the problem of pinpointing a moment in time as a restoration target, they suggest that restoration science should be forward looking, attempting to design and create ecosystems that will function best in the conditions of the future, rather than looking nostalgically to a past that is difficult, if not impossible, to recreate. Some have even gone so far as to propose new terms for the practice as an alternative to the backward looking focus of restoration, including "reconciliation ecology," "win-win ecology," or the oxymoronic "futuristic restoration" (Allison 2007, Choi 2007, Halle 2007). Still others raise the very real concern that 
environmental change on a global scale, particularly climate change, will make the restoration of historical ecological conditions at specific sites nearly impossible, as any attempt to maintain current biodiversity may have to shift focus toward aiding plant and wildlife communities re-establish themselves and adapt to rapidly shifting climate zones (Harris et al. 2006). In a world where base environmental conditions are changing rapidly everywhere, can history provide any reference points at all for site specific restoration projects? As forward looking restoration ecologists suggest, it may be very difficult to even imagine re-creating site specific ecological conditions in manner that conforms to even the recent past.

As compelling as these arguments are, the past may not be as inaccessible as the forward looking school of restoration ecology suggests. The science of restoration ecology has adopted techniques to account for historical variation and change over time. The use of reference sites-a relatively undisturbed site with similar historical ecological features to a disturbed site (akin to Shelford's binonomic baselines) - allows ecologists to create a comparative baseline from which to develop restoration goals and targets in terms of vegetation cover, soil conditions, and riparian habitat. Put simply, restoration ecologists might examine a relatively intact forest, river, or wetland in order to establish restoration goals for similar sites within a specific region, a technique often referred to as a space for time substitution (Arcese and Sinclair 1997, Sinclair, et al. 2004, White and Walker 1997). Ecologists need not completely abandon the analysis of historical ecological data in such situations, however, as a range of scientific techniques such as pollen analysis, dendrochronology, and historical modelling using biodiversity indices allow ecologists to analyze the historical range of variation in ecological conditions at specific sites (Brewer and Menzel, 2009, Davis and Watson 2007, Feest 2006, Jackson and Hobbs 2009, Lindblah et al., 2007,).

Aside from practical developments in research methods, history remains a critical component of the community-based and democratic culture surrounding the grassroots ecological restoration 
movement. Conversely, restoration unleashed from history promises to become more of a technical enterprise, devoted to questions such as the soil chemistry and hydrology of an engineered landscape rather than the critical issues of community memory and historical identity within particular environments. While some ecologists have criticized community-based approaches to restoration for their potential to compromise biodiversity outcomes and wilderness values (Throop and Purdom 2006), other scholars have advocated participatory approaches for their potential to connect communities and individuals with local environments (Burke and Mitchell 2007, Higgs, 2003, 2006). A large body of literature on traditional environmental knowledge (TEK) among Aboriginal peoples and local ecological knowledge (LEK) among resource users suggests that community consultations can offer at least a partial window on local historical ecological conditions (Berkes 1999, Ferguson and Messier 1997, Ferguson et al. 1998). Undoubtedly, participatory projects must grapple with the limitations of community memory (including the possibility of shifting baseline syndrome) and the potential for participatory restoration projects to focus more on aesthetics than biodiversity, what could be described as mere ecological gardening rather the re-establishing the full assemblage of previous flora and fauna. Scholars of human landscape perception have long argued that human fondness for certain types of topography or vegetation may shift dramatically over time, the most famous example being the changing perception of mountains in Europe and North America from blight to a glorious landscape in the eighteenth century (Nicholson 1959, Schama 1996, Tuan 1974). Yet it is precisely because humans invest landscapes with meaning that restoration ecologists must grapple with history and cultural identity when designing restoration projects. To take just one example, mine reclamation and restoration projects often provoke strong local objections when ecological goals threaten to completely remove all signs of the community's history of work within a mining landscape (Francaviglia 1991, Robertson 2006). Hence the notion of an adulterated return to baseline ecological conditions, or a forward-looking restoration of ecosystem services with no baseline reference, must in this case 
compete with the community-based desire to memorialize the full historical activities through which humans have shaped the former industrial site.

A historically informed approach to site-specific restoration also allows practitioners and affected communities to confront the social and political dimensions of environmental change. The broad emphasis on participatory grassroots action within the restoration literature often glosses over the potential for communities to resist restoration projects driven by the priorities of the state or private capital, particularly when they are associated with the uneven distribution of economic benefits and environmental liabilities of historical resource development patterns. Close attention to the historical political ecology of environmental change in degraded environments thus offers more than ecological data. History instead compels restorationists to confront the ways that conflicts over resource development and environmental injustices have influenced, and will continue to influence community perceptions of landscape and environmental change. As a recent collection of essays on restoration and environmental justice makes clear (Boyce et al. 2007), many communities at the economic margins, particularly in the Third World, conceptualize restoration not only as the re-creation of historical ecological conditions but also the restoration of local historical patterns of resource use, the reestablishment of historical rights of access to subsistence resources, the amelioration of inequitable patterns of environmental harms, and some sort of redress for the unequal distribution of benefits associated with large-scale resource development in traditional use areas.

Ecological restoration at the local level strikes at the heart of the core values and historical experiences that communities associate with their local landscapes. Although the central problems of historical imprecision and the misapplication of historical stasis to dynamic ecological systems remains inescapable, the restoration of natural sites without history threatens to unhinge human communities from the complex cultural, political, and ecological histories of environmental change in which they are embedded. To pursue restoration as a future oriented activity, with no reference to complex local 
histories of engagement with the environment, strips local communities of the only viable reference point-local knowledge of environmental change-with which they may participate democratically in the restoration process. Conversely, attempts to re-wild landscapes, particularly those that idealize a natural world without human history, threaten to ignore competing interpretations of historical environmental change and the social histories of conflict (based on class, race, gender, etc.) that often frame conservation and restoration initiatives. Who ultimately gets to decide what restoration is for: utility, aesthetics, biodiversity conservation, or the containment of industrial hazards? History may inform these questions even if an exact copy of historical ecological conditions is unobtainable. Although the direct engagement of communities is most paramount at the site-specific scale (the local stream, a community meadow, a degraded mine, etc.), many of the problems and prospects associated with history have also come to the fore when attempting to identify baselines for restoration at the landscape scale.

\section{The Landscape}

Landscape ecology, the newest sub discipline within ecology, has the potential to contribute a new perspective from which to view issues about restoration of species and sites, since landscapes are the context in which these are situated. While landscapes, by definition, can be scaled to encompass very large or very small extents, they are formally defined as heterogeneous areas composed of multiple habitat types (i.e., "sites") which interact spatially with each other (Turner et al. 2001). The frequently invoked analogy for landscapes is that of a "mosaic" of habitat patches - wherein each patch (or site, as described in the preceding section) has its own identifiable boundaries and identity but interacts with other patches to create a larger whole. For example, patches of forest stands of different age classes and species interact with patches of wetland, bog, and barrens in a boreal landscape. Some species may be exclusive to a single patch type/habitat, but others will make use of multiple patches through their 
life cycle and thus restoration of a single site may not be sufficient to ensure species restoration. Even less mobile species, such as epiphytic arboreal lichens, that spend their entire lifetime adhered to a single tree, may be affected by what happens in adjacent habitat patches. Research (Rheault et al. 2003) has shown that when adjacent stands are cut, the gap created affects the microclimate of a forest stand containing arboreal lichen. These changes can negatively affect the viability of the species and limit its potential to colonize new sites.

Although much of the practical implementation of ecological restoration is focused on the species or site/patch scale, some ecologists have suggested that restoration is more effective when it focuses on the landscape as a whole. The argument is that many ecological processes (e.g., water flow, fire, species dispersal) as well as anthropogenic effects (e.g., climate change, forest harvest, road building) operate at landscape scales and hence site-level restoration may not be sufficient to restore species or ecological processes. Thus, an individual site may be restored, but it may not be possible to maintain it in its restored state unless the surrounding landscape is also equally restored (see review in Holl et al. 2003) or unless there is continual and intensive management intervention within the site. Such site-level intensive management as part of restoration is quite prevalent (and more accepted) in European restoration projects (e.g., Owen and Mars 2000, Klimkowska et al. 2010). However, in much of North America, site/patch restoration without concomitant restoration of the surrounding landscape will inevitably result in the "islands of habitat" phenomena that so many smaller North American protected areas currently face (Gurd and Nudds 1999, Parks and Harcourt 2002).

As with site-level restoration, landscape-level restoration that is attempting to restore to some sort of historical state requires identification of a point in time to restore to, and techniques to determine the specific landscape components in existence at that historical point in time. Many of the techniques used to describe historical landscape conditions are similar to those for identifying site-level conditions that have already been mentioned; these include dendrochronology (e.g., Frelich and Lorimer 
1991), paleoecology (e.g., Marshall et al. 2009), and pollen analysis (e.g., Bush and Colinveaux 1994). Interestingly, pollen analysis has shown that some supposedly pristine tropical landscapes have been affected by human activities. In the Darien region of Panama, a relatively vast roadless area of jungle that was believed to be "untouched" by humans, pollen analysis detected ash and maize pollen in cores dating to 4000 years BP, suggesting a human agricultural presence. (e.g., Bush and Colinveaux 1994).

Other techniques for identifying historical landscape conditions have been developed to deal with the large spatial extent of many landscape-scale projects. Some of these draw on newer technologies and are unique from those for identifying past conditions at the species or site level, and enable us to view ecological processes at broader spatial extents. Tools and techniques at landscapescales include the use of historical maps and air photos combined with computer modelling in a Geographic Information Systems (GIS). Perhaps the most striking example of such a modelling exercise is the Wildlife Conservation Society's (WCS) Mannahatta Project (http://welikia.org/). Here, Sanderson and colleagues began with a 1782 British military map of the present-day island of Manhattan, and used a wide array of archival data sources (including subsequent maps, artist's drawings from the era, journal entries), combined with ground-truthing of contemporary geophysical features still present on Manhattan, archaeological evidence, pollen data, and space-for-time substitutions to model vegetation associations (Sanderson and Brown 2007, Sanderson 2009). The project took a decade to complete and the end products include a richly illustrated popular book, an online video, media profiles in the New York Times and National Geographic, and a highly interactive website. The project website (welikia.org) allows Manhattanites to enter their street address and see a Google earth view of Mannahatta, created in part with the same CGI technology used to make Hollywood films. Viewers can "fly" through and zoom in and out of the landscape of what their city block might have looked like from 1690. The project implicitly acknowledges that ecosystems are dynamic, because it enables visitors to the website to virtually "time travel" forward from 1690 to see images of how their city block has changed up to the 
present day. Although the project has resulted in a detailed description of an historical reference state, it is not a pre-cursor to an ambitious restoration project. Sanderson stresses that:

(t)he goal of the Mannahatta Project has never been to return Manhattan to its primeval state. The goal of the project is discover something new about a place we all know so well, whether we live in New York or see it on television, and, through that discovery, to alter our way of life. New York does not lack for dystopian visions of the future.... But what is the vision of the future that works? Might it lie in Mannahatta, the green heart of New York, and with a new start to history, a few hours before Hudson arrived that sunny afternoon four hundred years ago?" (Sanderson 2009, pg. 33).

Obviously the Mannahatta Project, while not focused on restoration, is an extraordinarily detailed example of the special emphasis that conservationists place on the period of time just prior to European contact with North America. However the Mannahatta Project, with its CGI technology and interactive website does come across as more akin to a virtual reality/video game-like manifestation of the past. Does this imply that restoring to past states is an unrealistic goal? Is it fantasy? Or is it just potential fodder for a Hollywood film? The WCS sees the project as having more value than a fantastical virtual time-travel tool but also is consciously not using it to advocate restoration of the island of Manhattan to an exact copy of the landscape the way Henry Hudson would have viewed it. Instead, the WCS is using the Mannahatta project to prompt public discussion on the ecological future of New York City. The book and website contain a number of images of what a more ecologically balanced New York City might look like. This includes utopian views of rooftop gardens, cleaner water, increased green space and more pedestrian friendly thoroughfares. The project imagines the future of Manhattan as the integration of historical environmental conditions with a future-oriented landscape appropriate to a large-scale sustainable urban environment. 
Casting a look back at past conditions, even while acknowledging that those conditions cannot be perfectly re-created, also raises the question of how far back those advocating landscape restoration should look for inspiration. The Mannahatta project focuses on early European contact as a critical juncture in time, while acknowledging that the Lanape people influenced their environment through agriculture and use of fire (Sanderson and Brown 2007, Sanderson 2009). A more extreme look back is the Pleistocene re-wilding campaign which advocates trying to restore North America to conditions it would have looked like circa 13,000 years ago (Donlan et al. 2006) by using taxonomically similar species from Africa and Asia to substitute for mammoths and sabre-toothed tigers. In some ways, the goal of establishing a "Pleistocene Park" in North America (Donlan et al. 2006) is not that different from the Victorian era collectors and naturalists who tried to ensure that North America's "original" fauna were represented in museums. Unlike museum collections, Pleistocene Park would contain live specimens of similar species, and would represent an earlier version of the "original" fauna of North America than those collected by the likes of Joseph Grinnell and his contemporaries.

Although having African and Asian species substitute for sabre toothed tigers and mastodons may seem akin to passing a student copy of a famous painting off as art restoration, pro-Pleistocene rewilding ecologists argue that including these fauna in North American ecosystems is necessary to restore important ecological relationships. While forward-looking restoration work emphasizes restoration of ecological processes, Donlan et al. (2006) feel that these activities focus more on current ecological interactions and not those interactions which have disappeared from the landscape. They argue that Pleistocene megafauna played large ecological and evolutionary roles in North America, affecting prey populations and species evolution through predation, and plant assemblages through herbivory. They propose that by introducing taxonomically similar large fauna, these processes can be restored to North America. However, critics of the Pleistocene re-wilding campaign argue that the old world species have not evolved with current North American fauna, that the climate and flora of present-day North America 
are very different from prehistoric times, and that there are risks of unexpected and unwanted interactions and the introduction of new diseases and parasites (Rubenstein et al. 2006, Oliveira-Santos and Fernandez 2009). In addition, arguments against Pleistocene re-wilding have been made on aesthetic, ethical, and economic grounds (Rubenstein et al. 2006).

If it is attempted at all, Pleistocene re-wilding will be implemented experimentally, in large, enclosed, highly controlled conditions. Pleistocene re-wilding will not create landscape-scale restoration of prehistoric conditions across North America, and thus appears, like aspects of the Mannahatta project, to be somewhat unrealistic. The argument for Pleistocene re-wilding does have some potential benefit in that it raises awareness that what we perceive as archetypal pristine baseline conditions (i.e., North America at the time of European contact) are - in ecological and evolutionary time scales - highly problematic. The climate of North America during the Pleistocene was much cooler than the present day. Perhaps in the light of future climate change, which is predicted to create warming over much of North America, we can use the historical data from the Pleistocene to remind ourselves of the vast changes a landscape can experience and use this knowledge as a means to acknowledge that future conditions may be quite different from what we currently know or think we know about the recent past. In direct contrast to the problems associated with future-oriented restoration, the Pleistocene rewilding proposal highlights the dangers of too slavish an adherence to one moment in the broad sweep of historical ecological change, with no accounting for how such a reconstructed faunal assembly will adapt to a vastly different ecological circumstances in the contemporary North American landscape. Trying to envision future landscapes with an eye to the past, as the WCS is trying to do with the Mannahatta Project, represents a much more viable way forward.

\section{Conclusion}


The conservation and restoration movements often invoke the environmental conditions of the past as a way to measure the ecological degradation associated with industrialization, economic expansion, population growth, and modernity. Traditional approaches to ecological restoration in North America used eclectic and incomplete evidence in an attempt to describe, and eventually re-establish, pre-European ecological conditions. Yet a growing body of historical and ecological knowledge is now placing activists and managers in an awkward position. Restoration requires historical baseline targets, but all such targets are arbitrary for ecosystems that are constantly changing and have always been doing so. This problem is compounded by the fragmentary, selective, and ambiguous nature of the historical record. The fallacy of a pristine, pre-contact wilderness has been largely discredited, but this shift in historical and ecological theory has left many practical conservation and restoration questions unanswered.

These problems have led some to argue that we should abandon history entirely. In an era of global environmental change, the ambiguities of the past and uncertainties of the future make history increasingly irrelevant. Instead, we are told, the "no-analog future" must include novel ecosystems that are the products of human design. Is there a third way-a different role for historical knowledge that seeks neither to recreate an imagined past nor to abandon history entirely?

For all these ambiguities and uncertainties, there are compelling arguments not to abandon history in conservation and restoration. The adoption of a completely forward looking perspective may bypass the problem of dealing with the past, but it leaves activists and managers with no guidance to determine their goals. The inherent difficulties of identifying ecological baselines should not disqualify historical knowledge from restoration and conservation projects, but rather challenge practitioners to incorporate more sophisticated historical analyses that account for the complexity and variation of change over time. The two extremes of conservation and restoration-those which treat ecosystems as static and unchanging museum pieces, and those which celebrate wholly invented landscapes as a viable 
ecological paradigm - both encourage the separation of humans from the crucial sense of place that is evident in historical memory and understanding. Recasting historical knowledge not as a narrow search for singular baseline conditions or specific population figure, but as a way to track multifaceted ecological changes over time, offers a middle ground where the past may inform but not determine the ecosystems of the future. The past may be imperfect as a model for the future, but it is an indispensible guide for understanding a world in flux.

\section{References}

Anderson, Katharine. 2006. Does History Count? Endeavour 30: 150-155.

Anderson, M. Kat, Michael G. Barbour, and Valerie Whitworth. 1997. A World of Balance and Plenty: Land, Plants, Animals, and Humans in a Pre-European California. California History 76: 12-47.

Arcese, Peter, and Anthony R.E. Sinclair. 1997. The Role of Protected Areas as Ecological Baselines. Journal of Wildlife Management 61: 587-602.

Allison, Stuart K. 2007. You Can't Not Choose: Embracing the Role of Choice in Ecological Restoration. Restoration Ecology 15, 4: 601-605.

Barrow, Mark. 2009. Nature's Ghosts: Confronting Extinction from the Age of Jefferson to the Age of Ecology, University of Chicago Press.

Berkes, Fikret. 2009. Sacred Ecology: Traditional Ecological Knowledge and Resource Management. Philadelphia: Taylor and Francis.

Berry, Kristin H., ed. 1984. The Status of the Desert Tortoise (Gopherus agassizii) in the United States, Desert Tortoise Council.

Bjorkman, Anne D., and Mark Vellend. 2010. Defining Historical Baselines for Conservation: Ecological Changes since European Settlement on Vancouver Island, Canada. Conservation Biology 24, 6: 1559-1568.

Bolster, Jeffrey W. 2008. Putting the Ocean in Atlantic History: Maritime Communities and Marine Ecology in the Northwest Atlantic, 1500-1800. The American Historical Review 113: 19-47. 
Boyce, James K. Sunita Narain, and Elizabeth A. Stanton, eds. 2007. Reclaiming Nature: Environmental Justice and Ecological Restoration. London: Anthem Press.

Brewer, Stephen J., and Timothy Menzel. 2009. A Method for Evaluating Outcomes of Restoration when no Reference Sites Exist. Restoration Ecology 17, 1: 4-11

Burke, Sarah M., and Neil Mitchell. 2007. People as Participants in Ecological Restoration. Restoration Ecology: 15, 2: 348-50.

Bury, Bruce R., and Paul Stephen Corn. 1995. Have Desert Tortoises Undergone a Long-Term Decline in Abundance? Wildlife Society Bulletin 23: 41-47.

Bush, Mark B., and Paul A. Colinvaux. 1994. Tropical Forest Disturbance: Paleoecological Records from Darien, Panama. Ecology 75, 6: 1761-1768.

Cronon, William. 1983. Changes in the land: Indians, colonists, and the ecology of New England, Macmillan.

Cronon, William. 1993. The Uses of Environmental History. Environmental History Review, 17,3: 1-22.

Crosby, Alfred W. 1986. Ecological Imperialism: The Biological Expansion of Europe. Cambridge: Cambridge University Press.

Choi, Young D. 2007. Restoration Ecology to the Future: A Call for a New Paradigm. Restoration Ecology 15, 2: 351-353.

Davis, Althea L., and Fiona Watson. 2007. Understanding the Changing Value of Natural Resources: an Integrated Paleoecological-historical Investigation into Grazing-woodland Interactions by Loch Awe, Western Highlands of Scotland. Journal of Biogeography 34: 1777-1791.

DeJohn Anderson, Virginia. 2004. Creatures of Empire: How Domestic Animals Transformed Early America. Oxford: Oxford University Press.

Denevan, William. 1992. The Pristine Myth: the Landscape of the Americas in 1492. Annals of the Association of American Geographers 82, 3: 369-385.

Dizard, Jan E. 2010. Uneasy Relationships Between Ecology, History, and Restoration. In Marcus Hall, ed. Restoration and History: The Search for a Usable Past. New York: Routledge,pp. 154-63.

Donlan, C. Josh, Joel Berger, Carl E. Bock, Jane H. Bock, David A. Burney, James A. Estes, Dave Foreman, Paul S. Martin, Gary W. Roemer, Felisa A. Smith, Michael E. Soulé, and Harry W. Greene. 2006. Pleistocene Rewilding: An Optimisitc Agenda for Twenty-First Century Conservation. The American Naturalist 168, 5: 660-681.

Eliot, Robert. 1982. Faking Nature. Inquiry 25: 81-93 
1997. Faking Nature: The Ethics of Environmental Restoration. London: Routledge Press.

Feest, Alan. 2006. Establishing Baseline Indices for the Quality of the Biodiversity of Restored Habitats Using a Standardized Sampling Process. Restoration Ecology 14, 1: 112-122.

Ferguson, Michael A., and François Messier. 1997. Collection and Analysis of Traditional Ecological Knowledge About a Population of Arctic Tundra Caribou. Arctic 50, 1: 17-28.

Ferguson, Michael A., Robert G. Williamson, and François Messier. 1998. Inuit Knowledge of Long Term Changes in a Population of Arctic Tundra Caribou. Arctic 51, 3: 202-219.

Foster, David R., Glenn Motzkin, Debra Bernardos, and James Cardoza. Wildlife Dynamics in the Changing New England Landscape. Journal of Biogeography 29: 1337-1357.

Francaviglia, Richard V. 1991. Hard Places: Reading the Landscape of America's Historic Mining Districts. lowa City: University of lowa Press.

Frelich, Lee E., and Craig G. Lorimer. 1991. Natural Disturbance Regimes in Hemlock-Hardwood Forests of the Upper Great Lakes Region. Ecological Monographs 61: 145-164.

Grinnell, Joseph. 1910. The Methods and Uses of a Research Museum. Popular Science Monthly LXXVII: 163-169.

Gurd, D. Brent, and Thomas D. Nudds. 1999. Insular Biogeography of Mammals in Canadian Parks: a Reanalysis. Journal of Biogeography 26: 973-982.

Halverson, Anders. 2010. An entirely synthetic fish: how rainbow trout beguiled America and overran the world, Yale University Press. . 2005. A Transatlantic History of Environmental Restoration. Charlottesville: University of Virginia Press.

Halle, Stefan. 2007. Science, Art or Application-the "Karma" of Restoration Ecology. Restoration Ecology 15, 2: 358-361.

Harris, James A., Richard J. Hobbs, Eric Higgs, and James Aronson. 2006. Ecological Restoration and Global Climate Change. Restoration Ecology 14, 2: 170-176.

Higgs, Eric. 2003. Nature by Design: People, Natural Processes, and Ecological Restoration. Cambridge: MIT Press. . 2005. The Two-Culture Problem: Ecological Restoration and the Integration of Knowledge. Restoration Ecology 13, 1: 159-164. . Restoration Goes Wild: A Reply to Throop and Purdom. Restoration Ecology 14, 4: 500-503. 
Hobbs, Richard J. 2007. Setting Effective and Realistic Restoration Goals: Key Directions for Research. Restoration Ecology 15: 354-357.

Holl, Karen D., Elizabeth E. Crone, and Cheryl B. Schultz. 2003. Landscape Restoration: Moving from Generalities to Methodologies. BioScience 53, 5: 491-502.

Jackson, Stephen T., and Richard J. Hobbs. 2009. Restoration in the Light of Ecological History. Science 325, 567: 567-568.

Jackson, Jeremy B.C., Karen Alexander, and Enric Sala. 2011. Shifting Baselines: The Past and the Future of Ocean Fisheries. Washington, D.C.: Island Press.

Jentsch, Anke. 2007. The Challenge to Restore Processes in Face of Nonlinear Dynamics-On the Crucial Role of Disturbance Regimes. Restoration Ecology 15, 2: 334-339.

Jordon, William R. 2003. The Sunflower Forest: Ecological Restoration and the New Communion with Nature. Berkeley: University of California Press.

Katz, Eric. 1992. The Big Lie: Human Restoration of Nature. Research in Philosophy and Technology 12: 231-241.

. 1995. The Problem of Ecological Restoration. Environmental Ethics 18, 2: 222-224. . 2002. Understanding the Moral Limits in the Duality of Artifacts and Nature: A Reply to Critics. Ethics and the Environment 7, 1: 138-146.

Klimkowska, Agata, Rudy Van Diggelen, Ab P. Grootjans, and Wiktor Kotowski. 2010. Prospects for fen Meadow Restoration on Severely Degraded Fens. Perspectives in Plant Ecology, Evolution and Systematics 12: 245-255.

Kloor, Keith. 2000. Returning America's Forests to their 'Natural' Roots. Science 287: 573-575.

Kohler, Robert. 2006. All Creatures: Naturalists, Collectors, and Biodiversity, 1850-1950, Princeton University Press.

Krech, Shepard. 1999. The Ecological Indian: Myth and History. New York: W.W. Norton and Company.

Kroll, Gary. 2008. America's Ocean Wilderness: A Cultural History of Twentieth-Century , Exploration University of Kansas Press.

Leviton, Alan E., and Michael L. Aldrich, eds. 2004. Museums and Other Institutions of Natural History: Past, Present, and Future, California Academy of Sciences.

Light, Andrew. 2009. Contrefaire l'art ou contrefaire la nature: I'analogie artistique pour la restauration écologique. Cybergeo: European Journal of Geography. Article 480. Put online on 14 décembre 2009, http://cybergeo.revues.org/22275. Consulted on 19 juillet 2011. 
Lindblah, Matts, Jörg Brunet, Gina Hannon, Mats Niklassen, Per Eliasson, Göran Eriksson, and Anders Eksstrand. 2007. Forest History as a Basis for Ecosystem Restoration-A Multidisciplinary Case Study in a South Swedish Temperate Landscape. Restoration Ecology 15, 2: 284-295.

Lotze, Heike K., and Boris Worm. 2009. Historical baselines for large marine animals. Trends in Ecology and Evolution 24: 254-262.

Lowenthal, David. 1985. The Past is a Foreign Country. Cambridge: Cambridge University Press. . 2010. Reflections on Humpty Dumpty Ecology. In Marcus Hall, ed. 2010. Restoration and History: The Search for a Usable Past. New York: Routledge, pp. 13-34.

Marshall, Frank E. III, G. Lynn Wingard, and Patrick Pitts. 2009. A Simulation of Historic Hydrology and Salinity in Everglades National Parks: Coupling Paleoecological Assemblage Data with Regression Models. Estuaries and Coasts 32: 37-53.

Myllantaus, Timo. 2010. Changing Forests, Moving Targets in Finland. In Marcus Hall, ed. Restoration and History: The Search for a Usable Past. New York: Routledge, pp. 46-57.

Nicolson, Marjorie Hope. 1959. Mountain Gloom and Mountain Glory: The Development of the Aesthetics of the Infinite. Ithaca: Cornell University Press.

Oliveira-Sandos, Luiz G.R., and Fernando A.S. Fernandez. 2009. Pleistocene Rewilding, Frankenstein Ecosystems, and an Alternative Conservation Agenda. Conservation Biology 24, 1:4-6.

Owen K.M., and Robert H. Marrs. 2000. Acidifying Arable Soils for the Restoration of Acid Grasslands. Applied Vegetation Science 3:105-116.

Parks, Sandy A., and Alexander H. Harcourt. 2002. Reserve Size, Local Human Density, and Mammalian Extinctions in U.S. Protected Areas. Conservation Biology 16(3):800-808.

Pauly, Daniel. Anecdotes and the shifting baseline syndrome of fisheries. Trends in Ecology \& Evolution 10: 430.

Pfadenhauer, Jörg. 2001. Some Remarks on the Socio-cultural Background of Restoration Ecology. Restoration Ecology 9, 2: 220-229.

Preston, William L. 2002. Post-Columbian Wildlife Irruptions in California: Implications for Cultural and Environmental Understanding. In Charles E. Kay and Randy T. Simmons, eds. Wilderness and Political Ecology: Aboriginal Influences and the Original State of Nature, University of Utah Press, pp. 111-140.

Pyne, Stephen. 1982. Fire in America: A Cultural History of Wildland and Rural Fire. Seattle: University of Washington Press. 
Rheault, Héloïse, Pierre Drapeau, Yves Bergeron, and Per-Anders Esseen. Edge Effects of Epiphytic Lichens in Managed Black Spruce Forests of Eastern North America. Canadian Journal of Forest Research 33, 1: 23-32.

Robertson, David. 2006. Hard as the Rock Itself: Place and Identity in the American Mining Town, University Press of Colorado.

Rubenstein Dustin R., Daniel I. Rubenstein, Paul W. Sherman, and Thomas A. Gavin. 2006. Pleistocene Park: Does Re-Wilding North America Represent Sound Conservation for the $21^{\text {st }}$ Century? Biological Conservation 132: 232-238.

Sáenz-Arroyo, Andrea, Callum M. Roberts, Jorge Torre, Micheline Cariño-Olvera and Roberto R. Enríquez-Andrade. 2005. Rapidly shifting environmental baselines among fishers of the Gulf of California. Proceedings of the Royal Society B 272: 1957-1962.

Sanderson, Eric V., and Marianne Brown. 2007. Mannahatta: An Ecological First Look at the Manhatttan Landscape Prior to Henry Hudson. Northeastern Naturalist 14, 4: 545-570. 2009. Mannahatta: A Natural History of New York City. New York: Harry N. Abrams.

Schama, Simon. 1996. Landscape and Memory. New York: Vintage.

Seton, Ernest Thompson. Lives of Game Animals, An Account of those Land Animals in America North of the Mexican Border, Which Are Considered "Game," Either Because They Have Held the Attention of Sportsmen, or Received the Protection of Law, Vol. 3, Charles T. Branford.

Shelton, Stephanie, and Floyd W. Weckerly. 2007. Inconsistencies in Historical Geographic Range Maps: The Gray Wolf as an Example. California Fish and Game 93: 224-227.

Sinclair, Anthony R.E., Simon A.R. Mduma, and Peter Arcese. 2004. Protected Areas as Biodiversity Benchmarks for Human Impact: Agriculture and the Serengeti Avifauna. Proceedings of the Royal Society London, Series B. 269: 2401-5.

Star, Susan Leigh, and James R. Griesemer. 1989. Institutional Ecology, 'Translations' and Boundary Objects: Amateurs and Professionals in Berkeley's Museum of Vertebrate Zoology. Social Studies of Science 19: 387-420.

Stewart, Mairi J. 2010. Does the Past Matter in Scottish Woodland Restoration? In Marcus Hall, ed. Restoration and History: The Search for a Usable Past. New York: Routledge, pp. 63-73.

Throop, William, and Rebecca Purdom. 2006. Wilderness Restoration: The Paradox of Public Participation. Restoration Ecology 14, 4: 493-499.

Tuan, Yi-fu. 1974. Topophilia: A Study of Environmental Perceptions, Attitudes and Values. Eaglewood Cliffs, New Jersey: Prentice-Hall. 
Turner, Monica G., Robert H. Gardner, and Robert H. O'Neill. 2001. Landscape Ecology in Theory and Practice. New York: Springer-Verlag.

Vera, Frans. 2010. The Shifting Baseline Syndrome in Restoration Ecology. In Marcus Hall, ed. Restoration and History: The Search for a Usable Past. New York: Routledge, pp. 98-110.

White, Peter S., and Joan L. Walker. Approximating Nature's Variation: Selecting and Using Reference Information in Restoration Ecology. Restoration Ecology 5, 4: 338-349.

Wilson, Robert M. 2010. Seeking Refuge: Birds and Landscapes of the Pacific Flyway, University of Washington Press.

Wright, George M., Joseph S. Dixon, and Ben H. Thompson. 1933. Fauna of the National Parks of the United States: A Preliminary Survey of Faunal Relations in National Parks, U.S. Government Printing Office. 